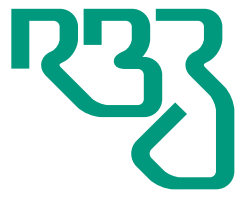

Revista

Brasileira de

Zootecnia

Brazilian Journal of Animal Science

ISSN 1806-9290

www.rbz.org.br

\section{Evaluation of some reproductive traits of Pelibuey ewes under humid tropical conditions of Mexico}

\author{
Carlos Luna-Palomera $^{1}$ (iD, Nadia Florencia Ojeda-Robertos ${ }^{2}$ (iD), \\ Jorge Alonso Peralta-Torres ${ }^{2}$ (iD), Ulises Macías-Cruz ${ }^{3}$ (iD), Fernando \\ Sánchez-Dávila $^{4}$ iD, José Candelario Segura-Correa ${ }^{5^{*}}$ iD \\ ${ }^{1}$ Universidad Juárez Autómoma de Tabasco, División Académica de Ciencias Agropecuarias, \\ Laboratorio de Reproducción y Genética Animal, Villahermosa, Tabasco, México. \\ ${ }^{2}$ Universidad Juárez Autómoma de Tabasco, División Académica de Ciencias Agropecuarias, \\ Villahermosa, Tabasco, México. \\ ${ }^{3}$ Universidad Autónoma de Baja California, Instituto de Ciencias Agrícolas, Valle de Mexicali, \\ Baja California, México. \\ ${ }^{4}$ Universidad Autónoma de Nuevo León, Campus de Ciencias Agropecuarias, Escobedo, \\ Nuevo León, México. \\ ${ }^{5}$ Universidad Autónoma de Yucatán, Campus de Ciencias Agropecuarias y Biológicas, \\ Mérida, Yucatán, México.
}

\begin{abstract}
We evaluated the effect of some environmental factors on age at first lambing (AFL) and lambing to conception interval (LCI) of Pelibuey ewes under the humid tropical conditions of Mexico. Ewes grazed on Tanzania (Panicum maximum), Bermuda (Cynodon dactylon), and Brachiaria grass (Brachiaria humidicola) and received hay in the corral in the months of grass scarcity. Reproduction was continuous during the year. Data of 839 lambings from 334 ewes registered from 2009 to 2017 were analyzed using survival analysis procedures. The statistical model for AFL included the effects of year, season, and litter size at lambing, whereas that for LCI included year and season plus parity number of ewe and litter size at weaning. The overall means \pm SD for AFL and LCI were $551.6 \pm 144.8$ and $145.4 \pm 113.1$ days, and their medians were 510 and 98 days, respectively. Only year of lambing had a significant effect on AFL, whereas LCI was affected by year, parity number, and litter size at lambing $(\mathrm{P}<0.05)$. Both AFL and LCI means did not show any trend with advancing years. The largest AFL and LCI means and medians corresponded to the first-parity ewes. In addition, single birth ewes had the longest LCI means and median. Therefore, year of lambing affects AFL, whereas year of lambing, parity number, and litter size at weaning affect LCI of Pelibuey ewes, indicating that these factors should be considered in the development of sound strategies to improve sheep production.
\end{abstract}

Keywords: age at first lambing, lambing to conception interval, parity number, tropics, survival analysis

\title{
Introduction
}

Sheep production is an important livestock activity in Mexico. In the tropics, Pelibuey sheep is the most important breed, being used as a pure or maternal breed for lamb production. Pelibuey sheep can be mated all year round; however, it shows poor reproductive and productive performance (Galina et al., 1996). 
Among reproductive traits, age at first lambing (AFL) and lambing to conception interval (LCI) are of significant economic importance. Those traits are influenced by genetic and environmental factors (Magaña-Monforte et al., 2013), so the knowledge of those factors is important to plan better management practices to improve Pelibuey ewe performance and profitability.

Environmental and management factors are very important because they influence the productive potential of an animal and the prediction of their genetic value. Therefore, their effects must be determined to apply sound management practices. Some authors have reported the effects of year, season, lambing, and nutritional management on the reproductive and productive performance of hair sheep breeds in the tropics (Galina et al., 1996; González-Garduño et al., 2001; Magaña-Monforte et al., 2013; Tec-Canché et al., 2016). However, those authors evaluated Pelibuey performance mainly under subtropical condition and used general linear models to test non-genetic factors. Humid tropical regions present similar average temperature but more rain and humidity than sub-humid regions, and management is not necessarily similar. Therefore, productive performance and effect of environmental factors may be different. On the other hand, the effect of non-genetic factors on AFL and LCI are commonly determined using general linear procedures, which suppose normality of data. However, another methodological approach is the use of survival analysis.

The objective of the present study was to determine the influence of some environmental factors on AFL and LCI of Pelibuey ewes under the humid tropical conditions of Mexico.

\section{Material and Methods}

We used information from production records (2009-2017) of Pelibuey ewes from a commercial ranch in the state of Tabasco, Mexico. The prevailing climate in the region is humid tropical with rain all year round $(2,550 \mathrm{~mm}$ average). Three seasons were identified according to temperature and rain data: dry (March to May), rainy (June to October), and windy (November to February). The maximum and minimum average temperatures are $36^{\circ} \mathrm{C}$ and $18.5^{\circ} \mathrm{C}$ with an annual average of $27{ }^{\circ} \mathrm{C}$. Relative humidity fluctuates between 60 and 95\% depending on the time of year (De Dios-Vallejo, 2001).

The production farm had two modules. One module with a house galley with mating pens, where the rams received the ewes after weaning. This module had an extension of 15 ha ( $50 \%$ high land and $50 \%$ flat-flood land) divided into three paddocks with 2 ha of Tanzania (Panicum maximum) and 9.5 ha of Bermuda grass (Cynodon dactylon), where they grazed during the day; in addition, there were 3.5 ha of corn for fodder. Matings were continuous throughout the year. The lots were made up based on the number of lambings at a given time. They were carried out simultaneously, mating five to eight batches of 25 to 30 ewes per ram. The duration of the breeding lasted up to three months. The second module (lambing place) received the pregnant ewes and had an extension of 5 ha provided with roofed galleys for lambing and for care of lambs. Lambs stayed in the pen with the dam with access to concentrate (creep feeding) until 60 days of age. Ewes went out to graze meadows with Panicum maximum and Brachiaria humidicola. After weaning, males were fattened for slaughter or used as rams, and replacement females were kept on raised floors until they reached the weight and age of breeding. Sheep received supplementation during early and late gestation, lactation, and breeding to meet the requirements according to the productive stage. Grass was harvested by ewes by direct grazing. However, ewes were given hay in the corral, mostly in the months of grass scarcity (dry and windy seasons).

Parasite control was performed with Famacha test every month and alternatively deworming with albedazole 2.5\% (Valbazen, Zoetis ${ }^{\circledR}$ ) and levamisole 12.0\% (Riperocol, Zoetis ${ }^{\circledR}$ ). Coproparasitoscopic test was carried out every three months. Vaccination (Clostridia and Pasteurella) was performed every six months with multibacterine toxoids (Barbac 10, Boehringer Ingelheim ${ }^{\circledR}$ ). The flock was free of Brucella ovis and Brucella abortus.

Information of 334 Pelibuey ewes registered from 2009 to 2017 was used. The database include the identification of ewe, date of birth of the ewe, date of lambing, type of lambing, year and month of 
lambing, and parity number. Age at first lambing and lambing interval were calculated from previous information. Lambing to conception interval was calculated by subtracting 150 days, the average gestation length (Carrillo et al., 1997) for Pelibuey, from the lambing interval. Furthermore, due to the poor low number of observations per year, data registered from 2009 to 2011 were combined in one group, as were data from ewes with $\geq 6$ lambings. In addition, litter size at lambing and weaning $\geq 2$ formed one group. Based on rainfall distribution and temperature, three seasons of lambing were established: rainy season (June to September), windy and wet season (October to January), and dry season (February to May).

We used data of 839 lambings from 334 ewes to determine the effect of some non-genetic factors on AFL or LCI after lambing through survival analysis. For comparison purposes, we applied the General Linear Model (GLM). If $\mathrm{T}$ denotes the time until first lambing or lambing to conception occurs, the survival function $\mathrm{S}(\mathrm{t})=\operatorname{Pr}(\mathrm{T}>\mathrm{t})$ indicates the probability that the event of interest has not occurred by time $\mathrm{t}$, in which: $\mathrm{S}(\mathrm{t})$ denotes the survivor function and $\mathrm{T}$ is the age at first lambing or conception of a randomly selected ewe.

The explicatory factors to explain AFL were year (2011 to 2017), season (dry, rainy, and wet and windy), and litter size at lambing (simple and multiple); for LCI, the factors were year of lambing, season of lambing, parity number $(1,2,3,4,5$, and $\geq 6$ ), and litter size at weaning (simple and multiple). We used The LIFETEST procedure, which computes nonparametric estimates of the survivor function by the product-limit method (also called the Kaplan-Meier method). The Kaplan-Meier estimate of the survivor function is:

$$
S\left(t_{i}\right)=\prod_{i=1}\left(1-\frac{d_{i}}{Y_{i}}\right)
$$

in which $\mathrm{S}\left(\mathrm{t}_{\mathrm{i}}\right)=$ survivor function, $\mathrm{t}_{\mathrm{i}}=$ distinct AFL or $\mathrm{LCI}, \mathrm{Y}_{\mathrm{i}}=$ number of ewes not lambing prior to time $t_{i}$, and $d_{i}=$ number of ewes that lamb at $t_{i}$. Test of differences between survival curves by strata (year, season, litter size, and parity number) were performed by means of the log-rank (LR) test:

$$
L R=2 N \log \left(\frac{T}{N}\right)-2 \sum_{k=1}^{k} N_{k} \log \left(\frac{T_{k}}{N_{k}}\right),
$$

in which $\mathrm{N}=$ total number of events (AFL or LCI), $\mathrm{N}_{\mathrm{k}}=$ total number of events in the $\mathrm{k}_{\mathrm{th}}$ group, $\mathrm{T}=$ total time on test, and $\mathrm{T}_{\mathrm{k}}=$ total time on test in the $k$-th stratum. The approximate probability value is calculated by treating LR as having a chi-square distribution with K-1 degrees of freedom.

All analyses were carried out using SAS (Statistical Analysis System, version 9.3).

\section{Results}

Overall means and standard deviations for AFL and LCI were 551.6 \pm 144.8 and $145.4+113.1 \mathrm{~d}$, and their medians 510 and $98 \mathrm{~d}$, respectively.

In this study, the GLM and survival analysis showed similar results for AFL, in which only year of lambing was significant $(\mathrm{P}<0.05)$. However, for $\mathrm{LCI}$, the GLM procedure showed only effect of year of lambing, whereas the survival analysis showed effect of year of lambing, litter size at weaning, and parity number $(\mathrm{P}<0.05)$.

Means and medians of AFL by year of lambing did not show any pattern with time. The lowest least squares mean and median happened in 2017 (497 and 490, respectively) and the highest in 2012 (594.0 and 564). Ewes born in the dry season tended to have a shorter AFL than ewes born in the rainy and windy seasons in the general model $(\mathrm{P}=0.0787)$ and survival procedures $(\mathrm{P}=0.0761)$. Means by type of lambing (single, multiple) were similar (550.1 and 554.2, respectively).

Means and medians of LCI by year of lambing did not show any trend by year. The highest least squares mean and median happened in 2012 (242.9 and 208, respectively) and the lowest in 2017 (98.0 and 90.5). Ewes having multiple births had lowest LCI mean (124.8) and median (93) than single-birth ewes 
(143.4 and 98 days, respectively). The medians for LCI decreased with parity number $(P=0.0001)$ in the survival analysis. First-parity ewes had the longest LCI median (112 d) compared to sixth-parity ewes (90 d) (Table 1 and Figure 1). Season of lambing was not significant in both procedures.

It was also observed that only 36.2 and $45 \%$ of first- and second-parity ewes had conceived before 90 days postpartum (Figure 1), whereas $50.4 \%$ of the sixth-parity ewes had already conceived. In addition, 6.45 and $1.44 \%$ of the ewes evaluated conceived after one and one and a half years after lambing, respectively.

\section{Discussion}

The GLM or analysis of variance procedures are commonly used to analyze response continuous data with normal distribution, whereas lifetable survival procedure is a non-parametric approach used to compare event time distribution of data. Preliminary test for normality of AFL and LCI data did not show normal distribution, even after transformation, using square root and natural logarithm functions. Therefore, discussion was based on survival analysis results, although least squares means are provided for literature comparison purposes. Lack of significance differences due to parity number and litter size at weaning for LCI under GLM procedure could be due to large coefficient of variation and thus standard error.

The AFL mean (551.6 days) here found is higher than the means reported by Magaña-Monforte et al. (2013), Andrade-Montoya et al. (2015), and Tec-Canché et al. (2016) for Pelibuey in Mexico (463.9, 477.0,

Table 1 - Least squares means \pm standard errors and medians by parity number of ewes for lambing to conception interval in Pelibuey sheep in the hot-humid tropics of Tabasco, Mexico

\begin{tabular}{lccc}
\hline Parity number & $\mathrm{n}$ & Mean \pm SE (days) & Median (days) \\
\hline 1 & 236 & $150.7 \pm 6.73 \mathrm{c}$ & 112 \\
2 & 181 & $135.0 \pm 7.85 \mathrm{~b}$ & 97 \\
3 & 150 & $133.6 \pm 8.41 \mathrm{~b}$ & 95 \\
4 & 104 & $131.8 \pm 9.93 \mathrm{~b}$ & 93 \\
5 & 78 & $116.8 \pm 11.42 \mathrm{a}$ & 92 \\
6 & 90 & $134.3 \pm 14.87 \mathrm{~b}$ & 90 \\
\hline
\end{tabular}

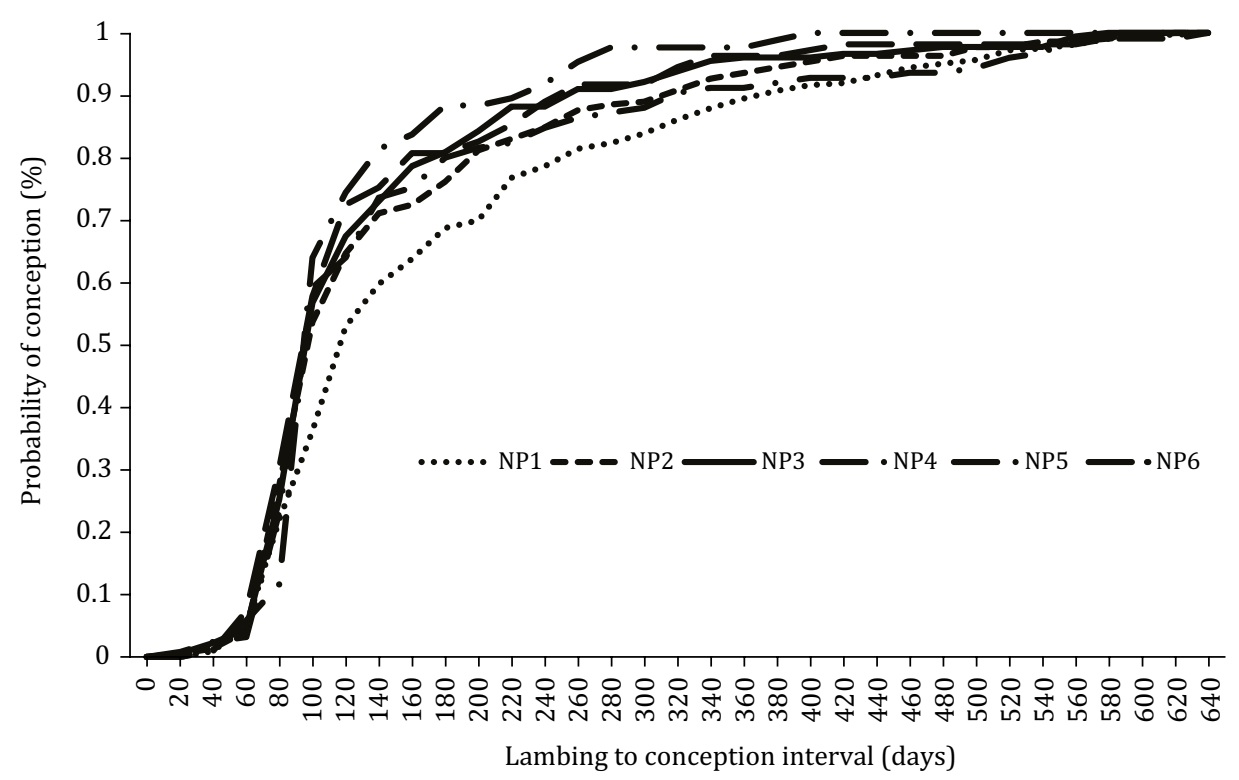

Figure 1 - Probability distribution by parity number for lambing to conception interval of Pelibuey ewes in the humid tropics of Tabasco, Mexico. 
and 526.7 days, respectively), but similar to the 557 days mean reported by González-Garduño et al. (2001), also under the tropical conditions of Mexico. Overall, 50\% of ewes lambed the first time at 510 days (17 months), $5 \%$ before one year, and $10 \%$ after two years of age.

Age of first lambing depends in part on the onset of puberty and the reproductive and nutritional management (Ramón-Ugalde and Sanguinés-García, 2002; González-Garduño et al., 2010). The effect of year could be due to changes in rain distribution, general management, and availability of forage among other unknown causes (Galina et al., 1996; González-Garduño et al., 2001; Andrade-Montoya et al., 2015). In addition, the difference between mean values of AFL could be attributed to differences between regions and animal management strategies. The lack of influence of season of lambing on AFL in the present study agree with previous results for Pelibuey sheep under tropical conditions (Magaña-Monforte et al., 2013; Tec-Canché et al., 2016). These data suggest that better management and nutrition are needed to improve the reproduction of first-parity ewes.

There are few papers analyzing LCI in Pelibuey sheep. However, the influences of factors here studied could be compared with the results of authors working with lambing interval. In the present study, LCI was calculated by subtracting 150 days from the lambing interval; therefore, significant effects shown in analysis of variance procedure will be the same for both LCI and lambing interval.

The LCI least squares mean found (145.4 days) in this study is higher than those means reported by other authors (subtracting 150 days from lambing interval mean). Lowest overall lambing interval means of 254, 274, 255.9, and 259.4 days were obtained by Galina et al. (1996), González-Garduño et al. (2001), Magaña-Monforte et al. (2013), and Tec-Canché et al. (2016) in Pelibuey ewes in the tropics of Mexico, corresponding to LCI of 104, 124.0, 105.9, and 109.4 days, respectively. However, they are similar to the value of 295.7 days of lambing interval notified by Andrade-Montoya et al. (2015). However, all lambing interval means are above the desirable value of 240 days to get three lambings in two years.

The longest LCI (150.7 days) of the first-parity cows could be attributed to their increased nutritional requirements to sustain their vital functions of maintenance, growth, and lactation in comparison with the old ewes, especially under extensive management conditions of the tropics. In addition, the shortest LCI of multiparous ewes, particularly those with five or more lambings could be explained by the fact that they may have suffered a process of selection from previous parities.

The survival analysis showed that the medians for LCI decreased with parity number up to 90 days, which is the appropriate time to get three lambings in two years in ewes. Therefore, a good practice to implement to improve reproduction in the flock is the energy supplementation of first-parity ewes during the months of food scarcity and the culling of those ewes kept in the flock without reproducing or lasting more than 120 days to conceive. The effect of parity has been reported as an important factor on LCI (López-Leyva et al., 2017) and lambing interval of Pelibuey sheep (Tec-Canché et al., 2016).

Litter size at weaning had an effect on LCI. However, contrary to other results, multiple-birth ewes had short LCI. It was expected that multiple-birth ewes had longer LCI because of more milk demand of twins or triplets, which can stimulate ewes to produce more milk for the lambs. This will stimulate the removal of body reserve for production, and when the body condition is poor, the resumption of ovarian activity is delayed. Similar results were reported by Dickson et al. (2004) and Magaña-Monforte et al. (2013).

In this study, season of the year was not an important factor influencing LCI. However, in other studies, lambing season has been an important source of variation for lambing interval, probably due to availability and better quality of forage in the best season. Magaña-Monforte et al. (2013) reported shorter LI in ewes lambing during the rainy season in the sub-humid tropics. Arroyo (2011) pointed out that during the rainy season, Pelibuey ewes had higher estrus activity and higher conception rates than in the dry season, and most of those effects are due to nutritional deficiencies and high temperature and humidity. 


\section{Conclusions}

Under the tropical conditions of this study, year of lambing affects age of first lambing, whereas year of lambing, parity number, and litter size at weaning affect lambing to conception interval of Pelibuey ewes, indicating that these factors should be considered in the development of sound strategies to improve sheep production.

\section{References}

Andrade-Montoya, A. M.; Torres-Hernández, G.; Martínez-Rojero, R. D.; González-Camacho, J. M.; González-Garduño, R. and Arece-García, J. 2015. Efecto del color de la capa externa en la edad al primer parto, prolificidad e intervalo entre partos en un rebaño de ovejas de pelo en Campeche, México. Archivos de Medicina Veterinaria 47:27-31. https://doi.org/10.4067/S0301-732X2015000100006

Arroyo, J. 2011. Estacionalidad reproductiva de la oveja en México. Tropical and Subtropical Agroecosystems 14:829-845.

Carrillo, L.; Segura-Correa, J. C. and Sarmiento, L. 1997. Algunos factores que determinan el período de gestación en ovejas de pelo. Revista Biomédica 8:15-20.

De Dios-Vallejo, 0. 0. 2001. Ecofisiología de los bovinos en sistemas de producción del trópico húmedo. Colección José N. Rovirosa. Villahermosa, Tabasco. México. 376p.

Dickson, L.; Torres-Hernández, G.; Aubeterre, R. D. and García, O. 2004. Factores que influyen en el intervalo entre partos y la prolificidad de un hato de carneros Pelibuey en Venezuela. Revista Cubana de Ciencia Agricola 38:13-17.

Galina, M. A.; Morales, R.; Silva, E. and López, B. 1996. Reproductive performance of Pelibuey and Blackbelly sheep under tropical management systems in México. Small Ruminant Research 22:31-37. https://doi.org/10.1016/09214488(95)00878-0

González-Garduño, R.; Torres-Hernández, G.; Becerril-Pérez, C. M. and Diaz, R. P. 2001. Relación del color del pelaje y factores ambientales con características reproductivas en ovejas tropicales. Agrociencia 35:41-50.

González-Garduño, R.; Torres-Hernández, G. and Arece-García, J. 2010. Comportamiento productivo y reproductivo de ovinos pelibuey en un sistema de pariciones aceleradas con tres épocas del año. Zootecnia Tropical 28:51-56.

López-Leyva, Y.; Arece-García, J.; Torrés-Hernández, G. and González-Garduño, R. 2017. Efecto del número de partos en el comportamiento productivo de ovejas Pelibuey y mestizos de Pelibuey en condiciones de producción. Pastos y Forrajes 40:73-77.

Magaña-Monforte, J. G.; Huchin-Cab, M.; Ake-López, R. J. and Segura-Correa, J. C. 2013. A field study of reproductive performance and productivity of Pelibuey ewes in Southeastern Mexico. Tropical Animal Health and Production 45:1771-1776. https://doi.org/10.1007/s11250-013-0431-2

Ramón-Ugalde, J. P. and Sanguinés-García, J. R. 2002. Response to ram effect on Pelibuey yearling ewes under grazing conditions and supplemented conditions in a tropical environment. Técnica Pecuaria en México 40:309-317.

Tec-Canché, J. E.; Magaña-Monforte, J. G. and Segura-Correa, J. C. 2016. Environmental effects on productive and reproductive performance of Pelibuey ewes in Southeastern México. Journal of Applied Animal Research 44:508-512. https://doi.org/10.1080/09712119.2015.1102730 